\title{
Influence of Transplanting Age on Paddy Yield under the System of Rice Intensification
}

\author{
Paul Reuben ${ }^{*}$, Zacharia Katambara² ${ }^{2}$ Fredrick C. Kahimba1, Henry F. Mahoo', \\ Winfred B. Mbungu1, Fikiri Mhenga ${ }^{1}$, Anthony Nyarubamba ${ }^{3}$, Muyenjwa Maugo ${ }^{3}$ \\ ${ }^{1}$ Department of Agricultural Engineering and Land Planning, Sokoine University of Agriculture (SUA), Morogoro, \\ Tanzania \\ ${ }^{2}$ Department of Built Environment Engineering, Mbeya University of Science and Technology (MUST), Mbeya, \\ Tanzania \\ ${ }^{3}$ Ministries of Agriculture, Food Security (MAFC), Dar es Salaam, Tanzania \\ Email: *reubenpal@gmail.com, reupal2003@yahoo.co.uk
}

Received 26 January 2016; accepted 21 March 2016; published 24 March 2016

Copyright (C) 2016 by authors and Scientific Research Publishing Inc.

This work is licensed under the Creative Commons Attribution International License (CC BY). http://creativecommons.org/licenses/by/4.0/

CC (i) Open Access

\begin{abstract}
Agronomic practices such as transplanting age, plant spacing, and water application regimes in irrigated paddy production can have a significant impact towards the performance in rice growth and yield. A study was conducted to investigate the optimum transplanting age for maximum rice productivity under the systems of rice intensification (SRI) technology. The study treatments adopted were three representing 8,12 and 15 days old seedlings replicated 3 times each. The experiment was set in randomized complete block design (RCBD) and transplanted at spacing $25 \mathrm{~cm}$ $\times 25 \mathrm{~cm}$ between rice hills. The rice variety tested was TXD 306 Super SARO, which was recommended by the ministry of Agriculture in Tanzania. Data was collected throughout the growing season in two mixed short rains and dry season of September 2013/2014 and September 2014/2015. Data collected included biomass at vegetative, flowering and harvesting stages, total number of tillers per hill, number of productive tillers per hill, number of grains per panicle and rice grain yield at the end of the season. Data was analyzed using SAS software version 9.1. The results suggested that transplanting at younger age of 8 to 12 days was recommended for Mkindo area in Mvomero Distirct, and other areas with similar soil conditions and agro ecological characteristics.
\end{abstract}

\section{Keywords}

SRI, Transplanting Age, Biomass, Tillers, Productive Tillers, Hill, Field Treatment, Yield

\footnotetext{
${ }^{*}$ Corresponding author.
}

How to cite this paper: Reuben, P., Katambara, Z., Kahimba, F.C., Mahoo, H.F., Mbungu, W.B., Mhenga, F., Nyarubamba, A. and Maugo, M. (2016) Influence of Transplanting Age on Paddy Yield under the System of Rice Intensification. Agricultural Sciences, 7, 154-163. http://dx.doi.org/10.4236/as.2016.73015 


\section{Introduction}

The Systems of rice intensification (SRI) has been reported as a rice cultivation practice that is characterized by water saving principles during rice production process [1]. This practice has become more suited in many rice production systems due to the stresses imposed on the already stressed water resources. These inevitable stresses result from the need to meet domestic water demands, irrigation water requirements and environmental requirements as well as the effect that climate change has on the water resources. SRI practices are comprised of a wide range of rice management principles that aims for higher yields while managing the water regime that ensures the wetting and drying practice other than the flooding practice that is cursed with the generation of methane gas that contributes to greenhouse gases [2].

The underlying principles of SRI practice within the growing season include seed sorting, sowing, application of organic fertilizer, transplanting younger seedlings and at wider spacings, weeding, and water management [1] [3] [4]. These principles have also been reported by other researchers such as [5]-[7]. In addition to the organic fertilizer being environmental friendly, it is affordable to rural small-holder farmers [8], it enriches the cultivated land with nutrient and organisms whose activities favour rice growth [4]. Intermittent wetting and drying practices allow weeds infestation that provides evidence of the existence of favourable soil conditions and the weeding process further improves the soil aeration of root zone by providing oxygen that facilitates the development of strong and healthy roots that leads to optimal tillering and development of healthy rice grains. [9] reported that frequency of weeding ranged between 3 - 4 times per rice growing season.

These and many other management practices implemented in SRI practices have been reported to considerably increasing rice grain yield [6]. For instance, studies on transplanting age have shown that rice seedlings transplanted at an earlier stage (8 - 16 days) contribute to higher grain yields [4]. However, the processes of transplanting younger seedlings should be carried out in a well-designed and levelled field to avoid irregular distribution of irrigation water that may lead to the submergence of the transplanted seedlings that consequently result to premature crop failure [10]. These and many technological aspects enhance sustainable high yield per unit area of rice production [11]. However, this technology requires high reliability of water so as to facilitate physiological and nutritional maintenance of the fields [9].

\section{SRI Practices' Crop Phenology Performance Indicators}

Tillers: Higher rice yields under SRI practices are evidenced by high number of tillers that are bearing panicle per unit area, number of rice grains per panicle, and high average weight of individual grains [4] [6] [12]-[15]. The process of transplanting rice seedling at its youngest possible age has been reported to contribute to higher tillering [14] [16]-[18] that contributes to higher yields.

Biomass: SRI practices has been reported to perform better in terms of the amount of roots, lesser days to flowering and harvest index [12] [14]. Different studies have suggested that achieving higher yields depends on increasing total crop biomass because proportion of the biomass is allocated to grain filling [6] [19]. The increase in crop biomass depends on crop photosynthesis and respiration losses. These factors depend on roots ability to extract nutrients in the soil, which is attained when the soil is aerated, the condition that defines SRI practice.

Panicle: Higher number of grains per panicle attained in SRI practice leads to higher yield of rice [12] [15]. It is therefore recommended to transplant rice at youngest possible age so as to get higher number of grains per panicle [17]. This increases number of filled grains per panicle and hence influences the level of rice yield at the end of the season.

Due to its proven potential in different areas of the world, SRI has now been adopted in Tanzania in recent years [1]. However, different parameters of SRI practice that fits Tanzania conditions including optimum transplanting age are still not well known. This limits its adoption rate in the country as farmers do not know exactly which transplanting age is most suitable for their local conditions. To answer these questions, experiments were conducted at Mkindo village, Mvomero district within Morogoro region, Tanzania with the main objective of investigating the optimum rice transplanting age, which will produce higher grain yield. To obtain this, yield contributing factors such as biomass, number of tillers and productive tillers per hill and number of grain per panicle were monitored. Data of yield contributing factors was collected in two dry seasons of 2013/2014 and 2014/2015. The treatments were T1, T2 and T3 representing rice seedlings transplanted at 8, 12 and 15 days old while other agronomic factors were uniformly applied in all treatments. These treatments were considered be- 
cause they are recommended by many researchers. Moreover, the research wanted to know if rice can be transplanted at the later age so as to minimize young seedlings handling challenges.

\section{Description of the Study Area}

Mkindo Irrigation Scheme is located in Mkindo village in Hembeti Ward, Mvomero District, Morogoro Region in Tanzania (Figure 1). Geographically, the Mkindo Irrigation Scheme lies between latitude $6^{\circ} 16^{\prime}$ and $6^{\circ} 18^{\prime}$ South and longitude $37^{\circ} 32^{\prime}$ and $37^{\circ} 36^{\prime}$ East The altitude ranges from 345 metres to slightly above 365 metres amsl. The study area is characterised by an average annual temperature of $24.4^{\circ} \mathrm{C}$, with a minimum of $15.1^{\circ} \mathrm{C}$ in July and a maximum of $32.1^{\circ} \mathrm{C}$ in February. The mean relative humidity is $67.5 \%$. The area has bimodal rainfall regime with short rains from October to December (OND) and long rains from March to May (MAM). The average total rainfall per year is between $1200 \mathrm{~mm}$ to $1500 \mathrm{~mm}$ [20].

The Mkindo rice irrigation scheme has a well-organized irrigation infrastructure (headwork on Mkindo Perennial River, partly lined main canal, and unlined secondary and tertiary canals, and drainage canals). The scheme was constructed in the period between 1980 and 1983. The scheme started producing rice in 1985 with only 17 ha under cultivation. Currently the scheme serves about 250 acres and a near future expansion is about 620 ha downstream of the current cultivated area.

The soils of Mkindo falls under WRB Soil sub unit Ferralic Cambisols with low natural fertility. The Reference Soil Group of the Ferralsols is deeply weathered, red or yellow soils of the humid tropics. The soils have diffuse horizon boundaries, a clay assemblage dominated by low activity clays (mainly kaolinite) and a high content of sesquioxides [21].

\section{Methodology}

\subsection{Investigation of Rice Transplanting Age}

The experiment to investigate rice transplanting age was conducted in two short rainy (vuli) cropping seasons of 2013/2014 and 2014/2015. In each season sampling was conducted and data was collected at different growth stages. The data included biomass, number of tillers per hill, number of productive tillers per hill, number of grains per panicle and grain yields at the end of the season.

\subsection{Experiment Set-Up}

The experimental site for rice transplanting age was located within Mkindo irrigation scheme and water was not a limiting factor during the growing season. This experiment was set in two dry seasons of September 2013/ 2014 and September 2014/2015 with three treatments, T1, T2 and T3 representing rice seedlings transplanted at 8, 12 and 15 days old, respectively (Figure 2). In this experiment all other agronomical practices were kept uniform in all the treatments.

The experiment was conducted using a field of $63.5 \mathrm{~m} \times 6.7 \mathrm{~m}$. Treatments were replicated 3 times each to form 9 sub plots of $8 \mathrm{~m} \times 6.7 \mathrm{~m}$, with buffer strips of $0.5 \mathrm{~m}$. The field trial experiments for each season were set in randomized complete block design (RCBD). The general field layout is as shown in the Figure 2.

The field preparation involved ploughing and pulverized by a power tiller and levelling. The rice variety used during the experiment was TXD 306 Super SARO which is recommended by the Ministry of Agriculture, Food Security and Cooperatives. All treatments were transplanted at a spacing of $25 \mathrm{~cm} \times 25 \mathrm{~cm}$. Transplanting was conducted using seedlings from one seedbed prepared following SRI principles in three different days. Treatments T1, T2 and T3 were transplanted using seedlings at age of 8, 12 and 15 days old. Spacing between rice hills were marked using a wooden space marker at $25 \mathrm{~cm} \times 25 \mathrm{~cm}$ spacing and one seedling was transplanted per rice hill.

\subsection{Biomass}

The sampling of the biomass was conducted in three phases during the growing season. The first phase was during vegetative stage (60 - 65 days from transplanting), flowering stage (85 - 90 days from transplanting), and at crop maturity/harvesting (110 - 115 days from transplanting). Rice biomass was harvested using knives and sickles. During harvesting, a tape measure was used to measure a randomly selected area of $1 \mathrm{~m}^{2}$ and then biomass was cut on the ground level in each plot. The harvested biomass was then packed in labelled bags for 


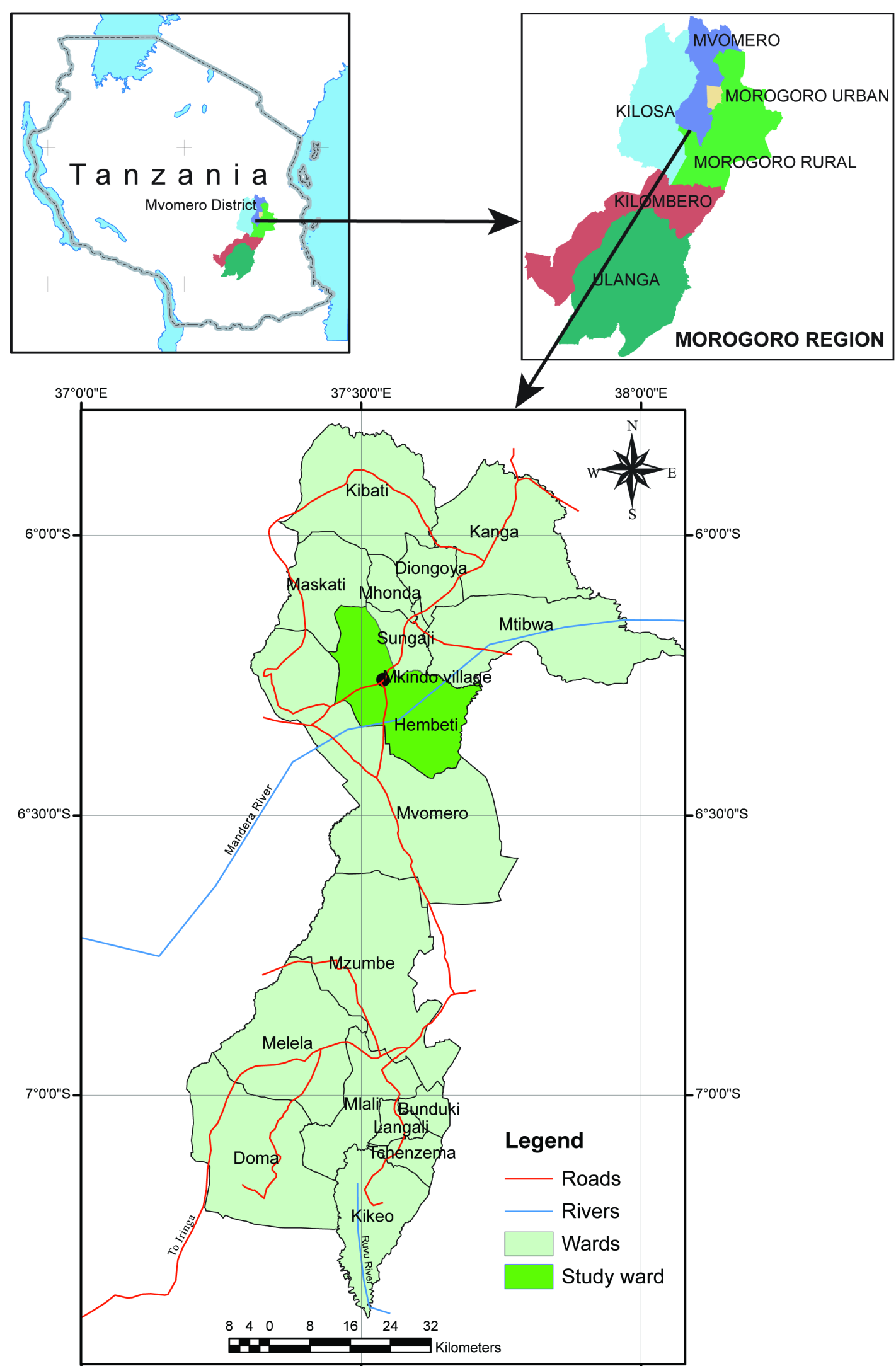

Figure 1. Location of the study area (Source: [22]). 


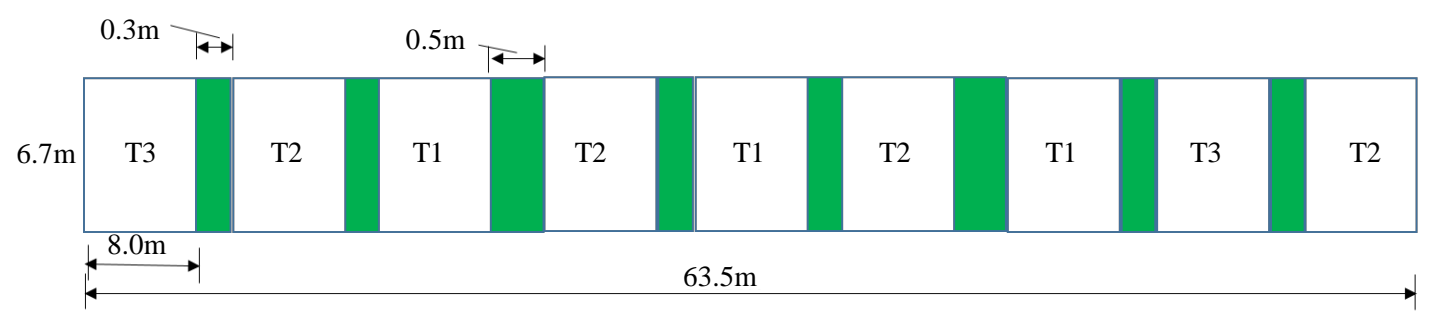

Figure 2. Transplanting age experiment layout.

identification purposes, finally sent to the Sokoine University of Agriculture laboratory for processing. At the laboratory, biomass was chopped into small pieces, weighed using measuring scale and then recorded on data recording sheet as a fresh weight biomass. For oven drying purposes, the sub sample biomass was taken from each biomass bag, reweighed again, labelled and then put in the oven which was set at a temperature of $70^{\circ} \mathrm{C}$ and then oven dried for 3 consecutive days. Re-weighing of the dry biomass was conducted after three days, then results were recorded for analysis. The following formula was used to calculate the crop biomass per hectare:

Netgross weight offresh biomass per square metre $=$ Gross weight - weight of the bag

Net subsample fresh weight $=$ Fresh subsample weight - weight of the bag

Gross weight of dry biomass per square metre $=\frac{\text { Dry sub sample weight }}{\text { Fresh sub sample weight }} \times$ Gross fresh weight

Gross dry biomass per hectare $=$ Gross weight per square metre $\times 10,000$

\subsection{Total Number of Tillers and Productive Tillers per Hill}

The number of tillers per hill in different treatments was monitored throughout the growing season. Data was collected from the random set experiment with three treatments and three replicates for each treatment. From each replicate, 5 hills were chosen randomly, marked with a thin stick pressed in the soil at early stages of plant growth. Tillers were manually counted in 2 weeks interval throughout the growing season and recorded in the data recording sheet for analysis. Number of productive tillers per hill was counted at crop maturity stage. This was considered to be an important factor to investigate the number of total tillers per hill against productive ones.

\subsection{Number of Grains per Panicle}

The number of grains per panicle was considered to be among of the factors contributing to rice yield. The higher the number of grains per panicle, the higher the rice yield. The randomly chosen 5 hills above were also used to estimate the number of grains per panicle at crop maturity. Numbers of grains in each panicle were counted, averaged and data was recorded in recording sheet for analysis.

\subsection{Yield}

Rice grain yield was estimated at the end of each cropping season (110 - 120 days after transplanting). In each subplot a tape measure was used to measure $1 \mathrm{~m}^{2}$ for harvesting samples for analysis. During harvesting rice panicles were cut and put into the labelled bag for further processing in the laboratory. At the laboratory rice seed was separated from straws, weighed using measuring balance and then recorded on data recording sheet as a fresh weight grains. The sub sample grains was taken from each bag, reweighed again, labelled and then put in the oven which was set at a temperature of $70^{\circ} \mathrm{C}$ and then oven dried for 3 consecutive days. Re-weighing of the dry grains was conducted after three to five days. Data was then recorded for analysis. The following formula was used to calculate the crop grain yield per hectare. 
Sub sample fresh weight $=$ Fresh sub sample weight $(g)$ - weight of the $\operatorname{bag}(g)$

Weight of dry subsample $=$ dry subsample weight - weight of the bag

Gross weight per square metre $=\frac{\text { Dry sub sample weight }}{\text { Fresh sub sample weight }} \times$ Gross fresh weight

Gross weight per heactre $=$ Gross weight per square metre $\times 10,000$

\subsection{Data Analysis}

Data analysis was conducted using the commonly used SAS version 9.1, a product from SAS institute Inc. The analysis employed the General Linear Model (GLM) procedures. The procedures followed include Analysis of variance (ANOVA) which was used to find variations that exist between seedlings transplanted at 8, 12 and 15 old day treatments in different crop yield indicators such as biomass, total number of tillers and productive tillers per hill; and number of grains per panicle. To control type I comparison-wise error rate of the treatments, the $\mathrm{t}$ test Least Square Difference (LSD) were followed provided that there is a significance difference between treatments. This similar methodology was used by several researchers [10] [17] [18].

\section{Results and Discussion}

\subsection{Biomass}

The crop dry biomass was investigated in three stages of crop cycle, these include vegetative, flowering and crop maturity stages. Results show that, there was no significant variation $(\mathrm{p}>0.05)$ at both vegetative, rice flowering and maturity stages non grain biomass respectively. At vegetative stage the biomass in tons per hectare were 3.03, 2.99, 2.57 and 1.19 for 8 days, 12 days, 15 days transplanting age treatments and non SRI experiments respectively (Figure 3).

At flowering stage the biomass in tonnes per hectare were 7.82, 8.05, and 7.45 for 8, 12, 15 days transplanting age treatments and non SRI, respectively (Figure 1) Whereas at harvesting stage it was 6.65, 6.22, 5.92 and 2.38 for 8, 12, 15 days transplanting age treatments and non SRI, respectively. The highest biomass was attained at flowering stage because the rice is at initial stage of grain filling.

\subsection{Number of Tillers per Hill at Different Periods and Productive Tillers per Hill}

The number of tillers per hill was also investigated at the interval of 14 days from transplanting to crop maturity (Figure 4). 14 days from transplanting, tillers was increased from 1 to 4.3, 3.9 and 3.9. Higher increase rate was attained between 14 and 35 days. In this period, the number of tillers per hill increased to 20.6, 19.9 and 20.7 for 8, 12 and 15 days old transplanted seedlings. Between the periods of 35 to 48 days, the increase in number of tillers per hill was much higher (43.9, 38.5 and 40.0); this might be contributed by the application of urea fertilizer. Between 48 and 70 days period, also the number of tillers increased to 54.4, 48.0 and 46.7, respectively. The maximum number of tillers per hill was found between the periods of 70 to 85 days. Here the number of tillers per hill increased to 58.1, 51.7 and 51 for the treatments in question. The counted number of tillers per hill at $104^{\text {th }}$ day after transplanting was $57.2,51.1$ and 49.3 respectively. The results show that, there was very insignificant mortality of tillers.

The analysis performed at 0.05 level of significant in separate periods, found that there was no significant difference in number of tillers per rice hill in periods between 0 days and 48 days after transplanting. The significance existed between the periods of 48 - 80 days. Here, 8 days seedlings performance was significantly higher than 12 and 15 days transplanted seedlings. Thus in terms of number of tillers per hill 8 days transplanted seedlings performed better as compared to the rest.

The comparison of number of total tillers per hill and productive tillers per hill was investigated during crop maturity (Figure 5). Results showed that there was no significant difference $(p>0.05)$ in number of productive tillers per rice hill for all the three treatments. The total number of tillers per hill was 58.2, 51.7 and 51.1 tillers for 8,12 and 15 days transplanting age, respectively. The number of productive tillers per hill was 55.6, 47.6 and 46.9. Unproductive tillers are normally formed due to late tillering of some tillers during rice growth stages. 


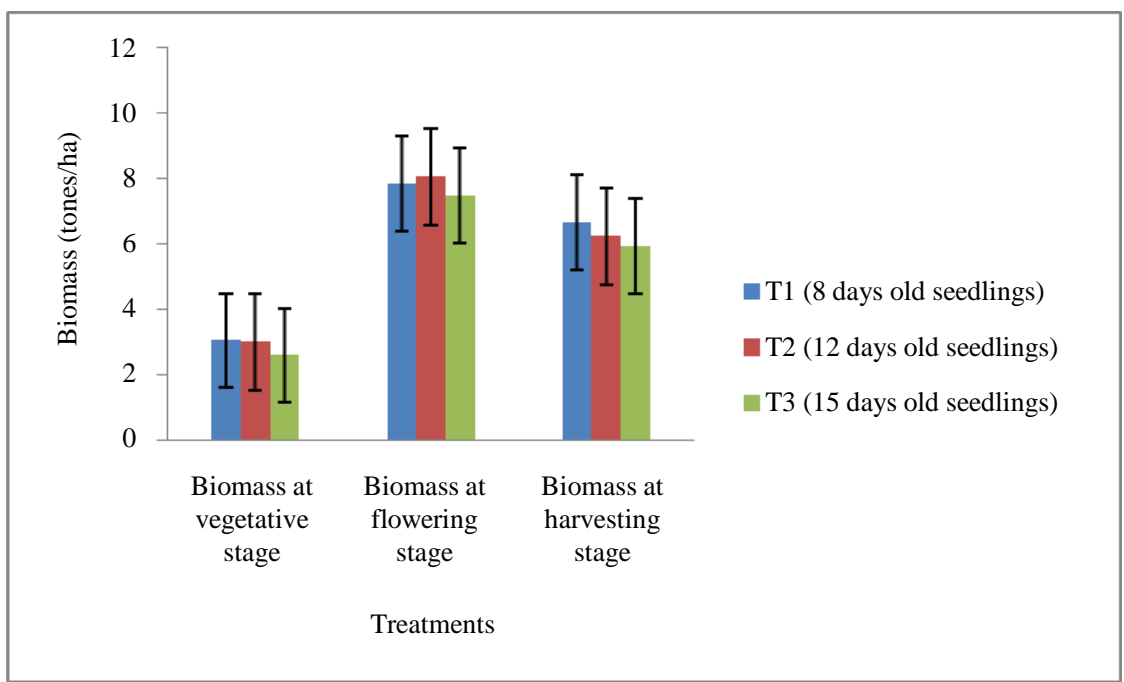

Figure 3. Dry biomass results for rice transplanted at different age and non SRI.

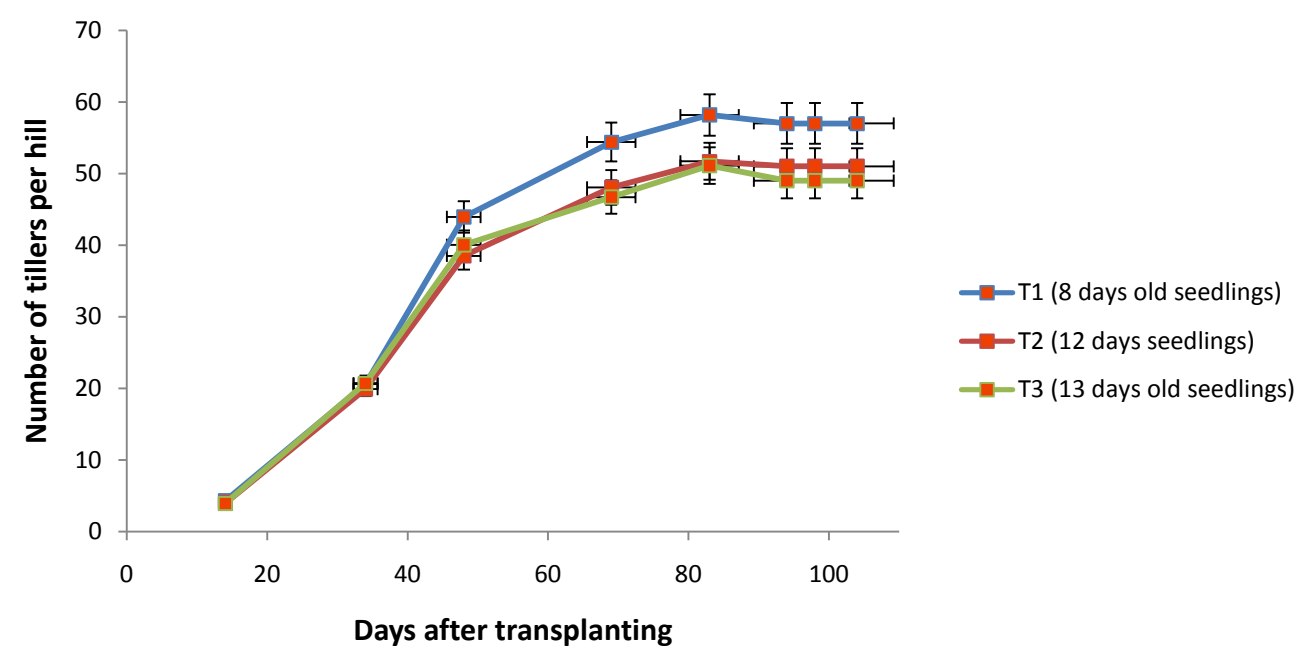

Figure 4. Number of tillers per hill in different rice age.

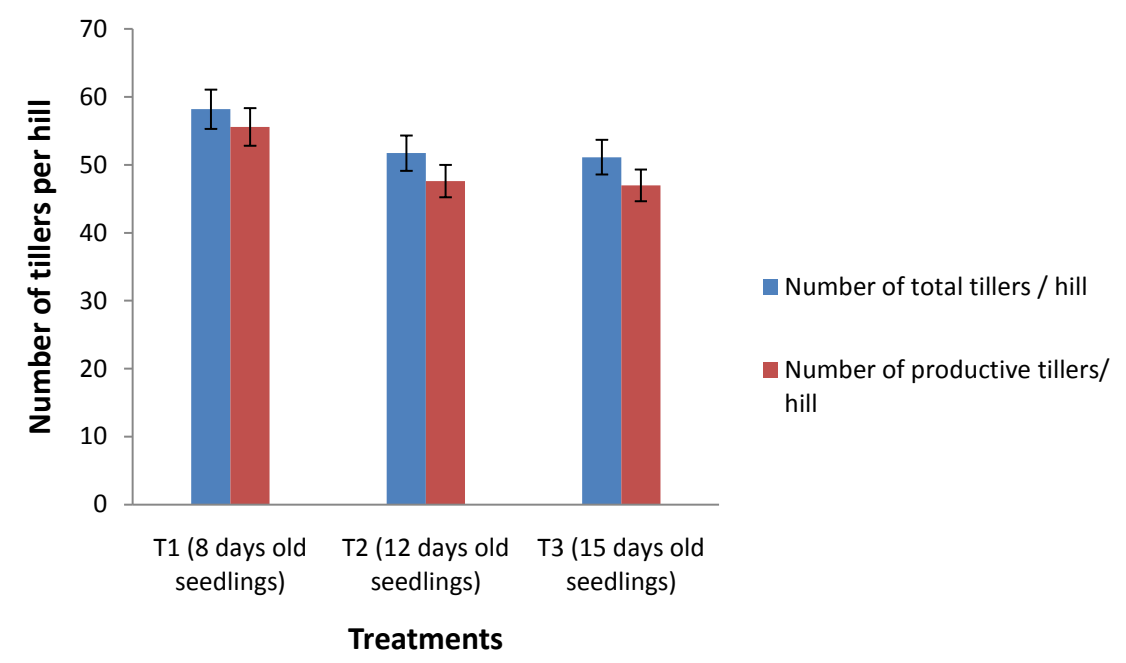

Figure 5. Comparison of productive and total number of tillers per hill. 


\subsection{Number of Grains per Panicle}

The results show that there is no significant difference $(p>0.05)$ of the number of grains per panicle between three treatments. This indicates that rice transplanting at age in question using SRI have the same influence in terms of number of grains per panicle performance. The average number of grains per panicle was 224.4, 218.1 and 202.1 for 8,12 and 15 days old transplanted rice seedlings respectively (Figure 6).

\subsection{Yield}

The yield for the three treatments was also investigated at the end of the season. No significant, differences ( $\mathrm{p}$ > 0.05) was observed in rice yield in all the three treatments though 12 days has a slight higher yield compared to other rice ages. The rice yield was 8.4, 8.5 and 8.1 tonnes/ha (Figure 7) for 8, 12 and 15 days old transplanted seedlings respectively. Therefore, from the results, and considering average performance of all parameters it can be concluded that transplanting at early stages of 8 - 12 days give better crop growth performance than 15 days. However, considering yield performance still the transplanting age range of 8 to 15 can be recommended for Mkindo area. However, the general trend of crop performance in different stages of rice growth shows that there is slightly higher performance on early transplanted seedlings ( 8 - 12 days).

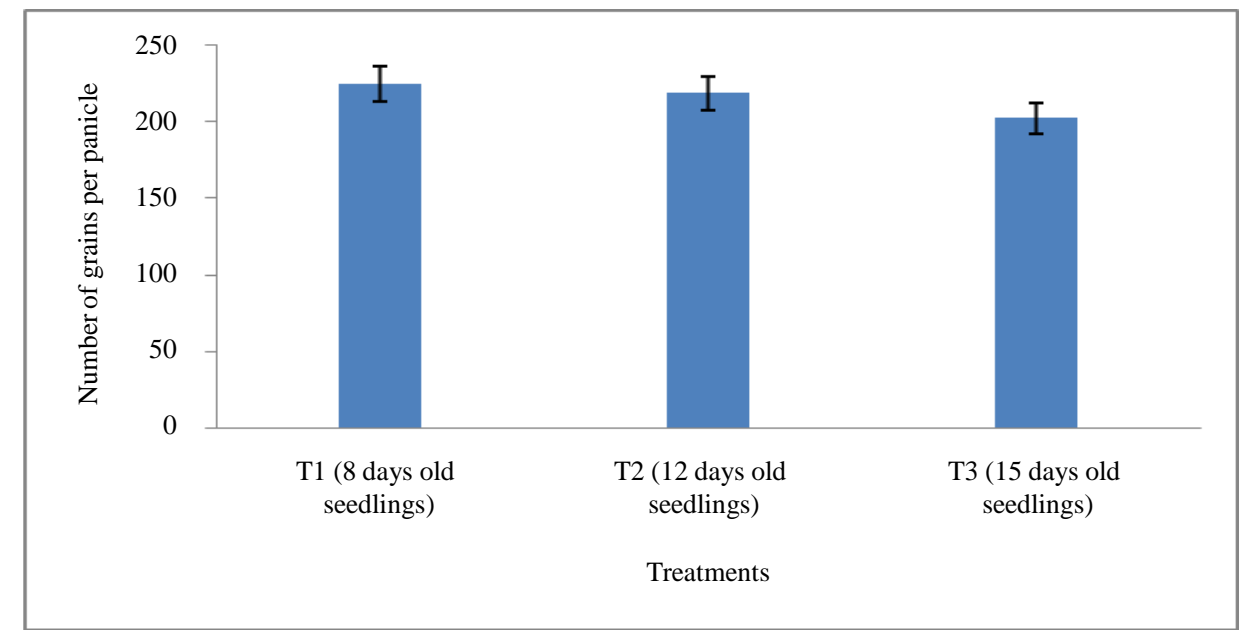

Figure 6. Number of grains per rice panicle for different treatments.

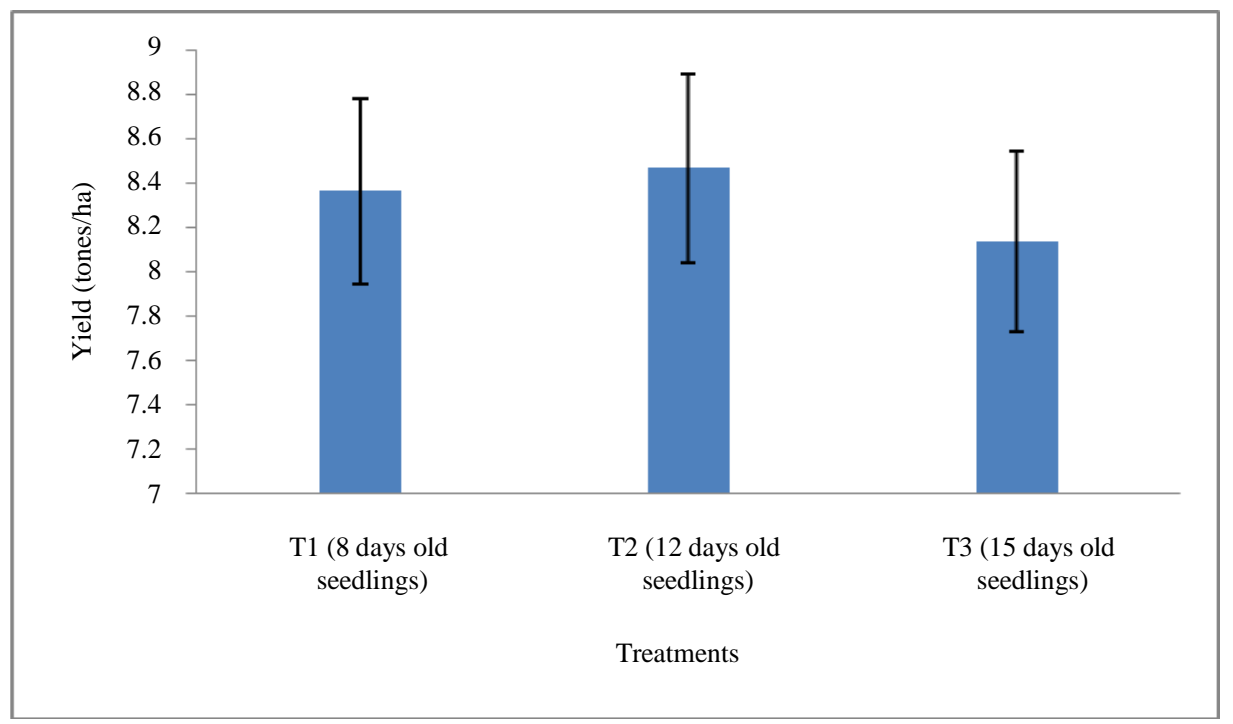

Figure 7. Rice yield at different transplanting age. 


\section{Conclusions}

The experiment is conducted to investigate the optimum transplanting age in SRI practice that will give maximum grain yield. This is done by monitoring some of yield indicators throughout the cropping season. The indicators leading to optimum yield include higher biomass, maximum number of tillers per hill leading into high productive tillers and higher number of grains per panicle. Treatments performed include rice transplanted at seedlings age of 8,12 , and 15 days old.

The results have shown no significant difference in biomass yield, number of tillers per hill, number of productive tillers per hill and number of grains per panicle. These results have led to insignificant difference in rice grain yield at harvesting between the three treatments.

It is therefore recommended that, rice seedlings can be transplanted at any age between 8 and 15 days. However, transplanting at earlier age ( 8 - 12 days) has shown to be more potential in terms of higher number of tillers per hill which in some cases may lead into higher yield of rice.

Moreover, because transplanting age difference between 8 and 15 days has shown to have no significant effect on rice yield in SRI practice, more trials need to be conducted on optimum transplanting spacing and irrigation water regime, which will produce highest significant rice yield difference. Answering these questions will help farmers to adopt the system easily and also using less water for irrigation as more irrigable area is expanding while the water resource remains the same.

\section{Acknowledgements}

The authors would like to thank the Tanzania Commission of Science and Technology (COSTECH) for the financial support, which enabled the implementation of the findings. Thanks also to the following institutions for their collaboration during conducting the study: Sokoine University of Agriculture (SUA), Ministry of Agriculture, Food Security and Cooperatives (MAFC), Mbeya University of Science and Technology (MUST), SUA Pest Management Centre (SPMC), and the Mkindo Farmers Training Centre.

Special thanks to the Mkindo Village Government and farmers of Mkindo Irrigation Scheme who tirelessly worked with the researchers in achieving the project objectives.

\section{References}

[1] Katambara, Z., Kahimba, F., Mahoo, H., Mbungu, W., Mhenga, F., Reuben, P., Maugo, M. and Nyarubamba, A. (2013) Adopting the System of Rice Intensification (SRI) in Tanzania: A Review. Journal of Agricultural Sciences, 4, 369375. http://dx.doi.org/10.4236/as.2013.48053

[2] Fazli, P. and Man, H.C. (2014) Comparison of Methane Emission from Conventional and Modified Paddy Cultivation in Malaysia. Agriculture and Agricultural Science Procedia, 2, 272-279.

[3] Latif, M.A., Ali, M.Y., Islam, M.R., Badshah, M.A. and Hasan, M.S. (2009) Evaluation of Management Principles and Performance of the System of Rice Intensification (SRI) in Bangladesh. Field Crops Research, 114, 255-262. http://dx.doi.org/10.1016/j.fcr.2009.08.006

[4] Stoop, W.A., Uphoff, N. and Kassam, A. (2002) A Review of Agricultural Research Issues Raised by the System of Rice Intensification (SRI) from Madagascar: Opportunities for Improving Farming Systems for Resource-Poor Farmers. Agricultural Systems, 71, 249-274. http://dx.doi.org/10.1016/S0308-521X(01)00070-1

[5] Debal, D., Jörg, L. and Marius, K. (2012) A Critical Assessment of the Importance of Seedling Age in the System of Rice Intensification (SRI) in Eastern India. Experimental Agriculture, 48, 326-346. http://dx.doi.org/10.1017/S001447971200004X

[6] Chapagain, T. and Yamaji, E. (2010) The Effects of Irrigation Method, Age of Seedling and Spacing on Crop Performance, Productivity and Water-Wise Rice Production in Japan. Paddy and Water Environment, 8, 81-90. http://dx.doi.org/10.1007/s10333-009-0187-5

[7] Stoop, W.A., Abdoulaye, A. and Amir, K. (2009) Comparing Rice Production Systems: A Challenge for Agronomic Research and for the Dissemination of Knowledge-Intensive Farming Practices. Agricultural Water Management, 1491-1501. www.els evier.com/locate/agwat http://dx.doi.org/10.1016/j.agwat.2009.06.022

[8] Glover, D. (2011) Science, Practice and the System of Rice Intensification in Indian agriculture. Food Policy, 36, 749-755. www.else vier.com/loc ate/foodpol http://dx.doi.org/10.1016/j.foodpol.2011.07.008 
[9] Laulanié, H.D. (2011) Technical Notes. Intensive Rice Farming in Madagascar. Tropicultura, 29, 183-187.

[10] Krupnik, T.J., Shennan, C., Settle, W.H., Demont, M., Ndiaye, A. and Rodenburg, J. (2012) Improving Irrigated Rice Production in the Senegal River Valley through Experiential Learning and Innovation. Agricultural Systems, 109, 101112. http://dx.doi.org/10.1016/j.agsy.2012.01.008

[11] Kima, A.S, Chung, W.G. and Wang, Y.-M. (2014) Improving Irrigated Lowland Rice Water Use Efficiency under Saturated Soil Culture for Adoption in Tropical Climate Conditions. Water, 6, 2830-2846.

www.mdpi.com/journal/water http://dx.doi.org/10.3390/w6092830

[12] Sinha, S.K. and Talati, J. (2007) Productivity Impacts of the System of rice Intensification (SRI): A Case Study in West Bengal, India. Agricultural Water Management, 87, 55-60. http://dx.doi.org/10.1016/j.agwat.2006.06.009

[13] Hasanuzzaman, M., Kamrun, N., Roy, T.S., Rahman, M.L., Hossain, M.Z. and Ahmed, J.U. (2009) Tiller Dynamics and Dry Matter Production of Transplanted Rice as Affected by Plant Spacing and Number of Seedling per Hill. Academic Journal of Plant Sciences, 2, 162-168.

[14] Chapagain, T., Riseman, A. and Yamaji, E. (2011) Assessment of System of Rice Intensification (SRI) and Conventional Practices under Organic and Inorganic Management in Japan. Rice Science, 18, 311-320. http://dx.doi.org/10.1016/S1672-6308(12)60010-9

[15] Singh, V.P., Shankar, U. and Bora, P. (2007) Feasibility Study to Support System of Rice Intensification (SRI). Study Conducted for Sir Dorabji Tata Trust, Mumbai.

[16] Pasuquin, E., Lafarge, T. and Tubana, B. (2008) Transplanting Young Seedlings in Irrigated Rice Fields: Early and High Tiller Production Enhanced Grain Yield. Field Crops Research, 105, 141-155. http://dx.doi.org/10.1016/j.fcr.2007.09.001

[17] Ginigaddara, G.A.S. and Ranamukhaarachchi, S.L. (2011) Study of Age of Seedlings at Transplanting on Growth Dynamics and Yield of Rice under Alternating Flooding and Suspension of Irrigation of Water Management. Recent Research in Science and Technology, 3, 76-88. www.recent-science.com

[18] Menete, M.Z.L., van Es, H.M., Brito, R.M.L., DeGloria, S.D. and Famba, S. (2008) Evaluation of System of Rice Intensification (SRI) Component Practices and Their Synergies on Salt-Affected Soils. Field Crops Research, 109, 3444. www.elsevier.com/locate/fcr http://dx.doi.org/10.1016/j.fcr.2008.06.003

[19] Belder, P., Bouman, B.A.M., Cabangon, R., Guoa, L., Quilang, E.J.P., Yuanhua, L., Spiertz, J.H.J. and Tuong, T.P. (2004) Effect of Water-Saving Irrigation on Rice Yield and Water Use in Typical Lowland Conditions in Asia. Agricultural Water Management, 65, 193-210. http://dx.doi.org/10.1016/j.agwat.2003.09.002

[20] Bracebridge, C. (2006) Mkindo Forest Reserve: Forest Disturbance Report. Report for Tanzania Forest Conservation Group and Participatory Environmental Management Programme, Dar es Salaam, Tanzania.

[21] ARI-Mlingano (2006) Soils of Tanzania and their Potential for Agriculture Development. Mlingano Agricultural Research Institute, Department of Research and Training, Ministry of Agriculture, Food Security and Co-Operatives, Tanga, Tanzania.

[22] Kombe, E. (2012) The System of Rice Intensification (SRI) as a Strategy for Adapting to the Effects of Climate Change and Variability: A Case Study of Mkindo Irrigation Scheme in Morogoro, Tanzania. Unpublished MSc Thesis, Sokoine University of Agriculture, Department of Agricultural Engineering and Land Planning. Morogoro, Tanzania. 